\title{
PEMANFAATAN EDMODO OLEH PENGAWAS SEKOLAH DALAM MEMBIMBING GURU MENYUSUN PROPOSAL PENELITIAN TINDAKAN KELAS
}

\section{Utilization of Edmodo by School Superintendent in Guiding Teacher Compose Classroom Action Research Proposal}

\begin{tabular}{|c|c|}
\hline Dinas Pendidik & $\begin{array}{l}\text { Sumarso } \\
\text { Pengawas SMP } \\
\text { dan Kebudayaan, Kabupaten Pandeglang, } \\
\text { Provinsi Banten, Indonesia } \\
\text { ramanegalih@gmail.com }\end{array}$ \\
\hline $\begin{array}{r}\text { Diterima: } \\
17 \text { Mei } 2019 \\
\text { Direvisi: } \\
03 \text { Desember } 2019 \\
\text { Disetujui: } \\
05 \text { Mei } 2021\end{array}$ & $\begin{array}{l}\text { ABSTRAK: Salah satu tugas pokok Pengawas Sekolah adalah } \\
\text { melakukan pembimbingan guru. Seiring dengan kemajuan } \\
\text { Teknologi Informasi dan Komunikasi (TIK), Pengawas Sekolah } \\
\text { dapat memanfaatkan kecanggihan TIK untuk mempermudah } \\
\text { tugas-tugas kepengawasan. Salah satu bentuk kemajuan TIK } \\
\text { yang dapat digunakan oleh Pengawas Sekolah dalam } \\
\text { melakukan pembimbingan guru adalah Edmodo. Edmodo } \\
\text { merupakan social network berbasis lingkungan sekolah } \\
\text { (school-based environment) yang dikembangkan oleh Nicolas } \\
\text { Borg and Jeff O'Hara, dengan fitur-fitur pendukung proses } \\
\text { belajar-mengajar. Penelitian dilakukan terhadap } 20 \text { orang guru } \\
\text { yang tergabung di dalam Musyawarah Guru Mata Pelajaran } \\
\text { (MGMP) Pendidikan Jasmani Olahraga dan Kesehatan. Melalui } \\
\text { Edmodo, Pengawas Sekolah melakukan penilaian terhadap } \\
\text { guru dengan menggunakan penilaian proses, penilaian } \\
\text { pengetahuan melalui kuis, dan penilaian produk berupa } \\
\text { Proposal Penelitian Tindakan Kelas (PTK) yang disusun guru } \\
\text { dan diunggah di Edmodo. Hasil penilaian menunjukkan rata- } \\
\text { rata untuk penilaian proses: } 71,25 \text {, penilaian kuis: } 80,80 \text {, dan } \\
\text { penilaian produk: } 84,90 \text {. Edmodo dapat digunakan Pengawas } \\
\text { Sekolah sebagai media untuk melakukan pembimbingan guru } \\
\text { secara jarakjauh. Pembimbingan yang dapat dilakukan dengan } \\
\text { memanfaatkan Edmodo adalah pembimbingan guru dalam } \\
\text { menyusun proposal PTK. }\end{array}$ \\
\hline
\end{tabular}

Kata Kunci: Edmodo, pengawas sekolah, guru, penelitian tindakan kelas.

ABSTRACT: One of the main tasks of School Superintendent is to guide teachers. As the Information and Communication Technology (ICT) develops, School Superintendents can take the advantage of it to facilitate their supervisory tasks. One of ICT development forms that can be used by School Superintendent in guiding teachers is Edmodo. Edmodo is a school-environment-based social network that is developed by Nicolas Borg and Jeff O'Hara, with learning-teachingprocess supporting features. The study is carried on to 20 teachers who are members of Subject Teacher Discussion Forum (MGMP) of Physical Education, Sports, and Health. 
Through Edmodo, School Superintendents assess teachers by using process assessment, knowledge assessment through quizzes, and product assessment in the form of Class Action Research proposals made by the teachers and uploaded into Edmodo. The assessment result shows that the mean of process assessment is 71.25; the knowledge assessment through quizzes is 80.80; and the product assessment is 84.90. Edmodo can be used by School Superintendents as a medium to conduct distant guidance to the teachers. Guidance that can be done by utilizing Edmodo is guiding teachers in arranging Class Action Research proposals.

Keywords: Edmodo, School Superintendent, Teacher, Class Action Research

\section{PENDAHULUAN}

Salah satu faktor penentu keberhasilan pembelajaran di sekolah adalah guru. Guru yang profesional diharapakan akan mampu meningkatkan mutu pembelajaran di sekolah. Peningkatan profesionalisme guru sangat ditentukan oleh banyak hal, salah satunya adalah pembimbingan dari Pengawas Sekolah.

Pengawas Sekolah sangat menentukan profesionalisme seorang guru dalam melaksanakan pembelajaran di sekolah. Salah satu tugas Pengawas Sekolah adalah melakukan pembimbingan dan pelatihan profesional guru. Sedangkan guru yang profesional harus memiliki seperangkat kompetensi. Salah satu kewajiban guru sebagaimana tercantum dalam UndangUndang RI No. 14 Tahun 2005 tentang Guru dan Dosen pada Bab IV Bagian Kedua Pasal 20 adalah bahwa dalam melaksanakan tugas keprofesionalannya guru wajib meningkatkan dan mengembangkan kualifikasi akademik dan kompetensi secara berkelanjutan sejalan dengan perkembangan ilmu pengetahuan, teknologi, dan seni. Hal tersebut dipertegas lagi dalam Peraturan Menteri Pendidikan Nasional RI Nomor 16 Tahun 2007 tentang Standar Kualifikasi Akademik dan Kompetensi Guru yang menyatakan bahwa salah satu kompetensi guru dalam bidang Pedagogik adalah memanfaatkan Teknologi Informasi dan Komunikasi (TIK) untuk kepentingan pembelajaran yang diampu.
Integrasi TIK dalam pembelajaran telah menjadi sebuah tuntutan sehingga tidak ada pilihan lain, semua guru harus belajar TIK (Susilawati, 2016: 350). Disebutkan juga bahwa salah satu kompetensi guru dalam hal profesionalitas adalah memanfaatkan TIK untuk mengembangkan diri, yaitu memanfaatkan TIK dalam berkomunikasi dan pengembangan diri. Artinya adalah bahwa Pengawas Sekolah mempunyai tanggung jawab untuk memberikan bimbingan kepada guru dalam memanfaatkan TIK dalam pembelajarannya. Tanggung jawab tersebut dapat terlaksana dengan baik bila Pengawas Sekolah sendiri menguasai dan menerapkan TIK dalam tugas kepengawasannya.

Dengan demikian, penerapan TIK oleh guru-guru binaan dalam proses pembelajarannya dapat terlaksana, karena adanya dukungan, contoh, dan motivasi dari Pengawas Sekolah, seperti disebutkan:

To successfully initiate and implement educational technology in school's program depends strongly on the teachers' support and attitudes. It is believed that if teachers perceived technology programs as neither fulfilling their needs nor their students' needs, it is likely that they will not integrate the technology into their teaching and learning. Among the factors that influence the successful integration of ICT into teaching are teachers' attitudes and beliefs towards technology (Andoh, 2012: 138).

Maksudnya adalah bahwa keberhasilan penerapan TIK dalam pembelajaran di sekolah sangat bergantung pada dukungan 
dan sikap guru. Dipercaya bahwa jika para guru menganggap program teknologi tidak memenuhi kebutuhan mereka dan kebutuhan siswa mereka, kemungkinan mereka tidak akan mengintegrasikan teknologinya ke dalam pengajaran dan pembelajaran mereka. Di antara faktor-faktor yang mempengaruhi keberhasilan integrasi TIK dalam pengajaran adalah sikap dan kepercayaan guru terhadap teknologi. Di sinilah peranan seorang Pengawas Sekolah dibutuhkan untuk memberikan motivasi kepada guru binaan untuk berupaya menguasai TIK yang dapat diaplikasikan dalam pembelajarannya, dan Pengawas Sekolah dapat memberikan contoh dengan menerapkan dan menggunakan TIK dalam berbagai kegiatan kepengawasan seperti pembinaan guru, supervisi, maupun dalam kegiatan-kegiatan kepengawasan yang lain.

Salah satu bentuk pemanfaatan TIK oleh Pengawas Sekolah dalam meningkatkan profesionalitas guru adalah pemanfaatan Edmodo dalam membimbing guru menyusun Proposal Penelitian Tindakan Kelas (PTK). Pemanfaatan media e-learning seperti Edmodo sebagai sarana pendukung untuk kegiatan pembinaan guru oleh Pengawas Sekolah diharapkan dapat meminimalkan hambatan waktu dan jarak, serta membantu meningkatkan kemampuan guru dalam menyusun Proposal PTK.

Berdasarkan uraian di atas, penulis sebagai Pengawas Sekolah ingin menjelaskan bagaimana bentuk pemanfaatan Edmodo oleh Pengawas Sekolah dalam kegiatan pembimbingan guru dalam menyusun proposal PTK.

\section{METODA}

Penelitian ini menggunakan metode penelitian deskriptif. Metode deskriptif adalah metode penelitian yang berisi pemaparan atau penggambaran sesuatu. Metode deskriptif termasuk metode yang paling banyak digunakan dalam studi penelitian pendidikan (Muliawan, 2014: 84). Nassaji (2015) berpendapat: "Qualitative and descriptive research methods have been very common procedures for conducting research in many disciplines, including education, psychology, and social sciences." Menurut Sukmadinata (2015: 73), penelitian deskriptif tidak memberikan perlakuan, manipulasi atau pengubahan pada variabel-variabel bebas, tetapi menggambarkan suatu kondisi apa adanya. Penggambaran kondisi bisa individual atau kelompok, dan menggunakan angka-angka. Pendapat lain mengatakan: "Descriptive research design is a scientific method which involves observing and describing the behavior of a subject without influencing it in any way. Many scientific disciplines, especially social science and psychology, use this method to obtain a general overview of the subject (Shuttleworth, 2019)", yang artinya bahwa desain penelitian deskriptif adalah metode ilmiah yang melibatkan pengamatan dan penggambaran perilaku subjek tanpa mempengaruhinya dengan cara apa pun. Banyak disiplin ilmu, terutama ilmu sosial dan psikologi, menggunakan metode ini untuk mendapatkan gambaran umum tentang subjek.

Penelitian ini mendeskripsikan atau menggambarkan kegiatan yang telah dilakukan Pengawas Sekolah dalam melakukan pembimbingan guru menyusun proposal PTK dengan menggunakan platform Edmodo. Sampel dalam penelitian ini adalah guru-guru yang tergabung dalam Musyawarah Guru Mata Pelajaran (MGMP) Pendidikan Jasmani Olahraga dan Kesehatan (PJOK) SMP di Kabupaten Pandeglang sebanyak 20 orang. Waktu pelaksanaan penelitian dilaksanakan dalam rentang waktu 03 Juli s.d. 30 Juli 2017.

\section{HASIL DAN PEMBAHASAN}

\section{Edmodo}

Kemajuan TIK diakui telah merambah ke semua bidang kehidupan, termasuk bidang pendidikan. TIK diciptakan untuk membantu dan mempermudah kehidupan manusia, dan berpengaruh positif terhadap pendidikan seperti pendapat Andoh (2012) yang mengatakan: "Information Communication and Technologies (ICT) have brought 
Sumarso: Pemanfaatan Edmodo oleh Pengawas Sekolah dalam Membimbing Guru Menyusun Proposal Penelitian Tindakan Kelas

remarkable changes in the twenty-first century, as well as affected the demands of modern societies. ICT is becoming increasingly important in our daily lives and in our educational system. Therefore, there is a growing demand on educational institutions to use ICT to teach the skills and knowledge students need for the 21st century" yang artinya bahwa TIK telah membawa perubahan luar biasa pada abad kedua puluh satu, serta memengaruhi tuntutan masyarakat modern. TIK menjadi semakin penting dalam kehidupan kita sehari-hari dan dalam sistem pendidikan kita. Oleh karena itu, ada peningkatan permintaan pada institusi pendidikan untuk menggunakan TIK dalam mengajarkan keterampilan dan pengetahuan yang dibutuhkan siswa abad ke-21.

Berdasarkan pendapat tersebut, disebutkan bahwa TIK berperan sangat penting dalam kehidupan masyarakat termasuk dalam bidang pendidikan dan pengajaran. Kemajuan bidang TIK yang dimanfaatkan dalam bidang pendidikan antara lain pemanfaatan media pembelajaran berbasis TIK di kelas, pengelolaan sistem informasi manajemen sekolah yang berbasis TIK, pengolahan nilai hasil belajar siswa yang menggunakan aplikasi berbasis TIK, dan pemanfaatan TIK untuk pembelajaran secara dalam jaringan (online) yang sering kita dengar dengan istilah e-Learning.

Pada saat sekarang, banyak sekali platform e-Learning yang telah diciptakan dan dapat dimanfaatkan untuk kegiatan pembelajaran secara dalam jaringan. Salah satu platform e-Learning atau digital class yang sudah banyak dimanfaatkan oleh pengajar untuk pembelajaran secara daring adalah Edmodo.

Edmodo merupakan social network berbasis lingkungan sekolah (schoolenvironment-based) yang dikembangkan oleh Nicolas Borg and Jeff O'Hara, dengan fiturfitur pendukung proses belajar-mengajar. Edmodo dapat diakses bebas di www.edmodo.com oleh guru, siswa, maupun orang tua siswa (Mahendrati Dwiharja, Laksmi, 2015:335). Edmodo merupakan sebuah kemajuan Teknologi Informasi yang fleksibel dan mudah, serta sangat membantu dalam pembelajaran, seperti pendapat berikut ini: "Edmodo is an incredibly flexible and powerful educational tool that can be adapted and used in just about any class in a variety of ways. How I use Edmodo and how you would use Edmodo could be totally different depending on what you are teaching, the temperament of your students and the environment you work in (Ris, Anti. 2016:3)".

Pemanfaatan e-Learning khususnya Edmodo sangat membantu guru dan siswa dalam proses pembelajaran karena dapat dilakukan di mana saja dan guru pun terbantu untuk mengunggah bahan ajar yang dapat diunduh oleh siswa kapanpun. Hal ini seperti pendapat Widiyasari (2017:32) yang mengatakan bahwa Edmodo memfasilitasi elearning sehingga pembelajaran dapat dilakukan di berbagai tempat. Edmodo juga membantu guru yang tidak bisa mengajar di kelas dengan memberikan materi pembelajaran secara online dengan mengupload materi belajar. Guru bisa memberikan tugas yang bisa ditentukan waktu pengumpulannya berikut menilainya. Guru juga dapat menggunakan Edmodo untuk menginstruksikan, menetapkan, dan membicarakan dengan siswanya secara online di waktu yang sama secara bersamaan. Mudah untuk mengirim berkas, gambar, video dan link, pesan individu ke pengajar, serta membuat grup untuk diskusi tersendiri menurut kelas atau topik tertentu (Watoni et al, 2017:44). Marzal (2014) mengatakan situs ini menyediakan cara yang sederhana bagi dosen dan mahasiswa untuk terhubung dan kerjasama secara virtual. Sebagai contoh, dosen dapat mengirimkan kuis dan tugas, memberikan umpan balik, menerima tugas yang diselesaikan oleh mahasiswa, memberikan penilaian, melakukan jajak pendapat, menyimpan dan membagi materi belajar dalam bentuk file maupun tautan (link), dan mengirimkan pesan atau peringatan kepada seluruh peserta grup belajar.

Edmodo adalah platform media sosial yang sering digambarkan sebagai Facebook untuk sekolah dan dapat berfungsi lebih banyak lagi sesuai dengan kebutuhan. Edmodo merupakan aplikasi yang menarik 
bagi guru dan siswa dengan elemen sosial yang menyerupai Facebook, tetapi sesungguhnya ada nilai lebih besar dalam aplikasi edukasi berbasis jejaring sosial ini (Rismayanti, Anti. 2012:1), seperti tulisan dengan judul "20 Ways to Use Edmodo (Teacher)" pada website https:// support.edmodo.com/ yang menyatakan bahwa manfaat yang dapat diambil guru dengan memanfaatkan Edmodo antara lain adalah: (a) Assessments; (b) Role Playing; (c) Peer Reviews \& Critiques; (d) Writing Projects; (e) Build Digital Citizenship Skills; (f) Foreign Language Practice; (g) Book Clubs; (h) Professional Development Workshops; (i) Cultural Exchange Projects; (j) Sub-Hub; (k) Backchannel Discussions; ((I) Science Probes; $(m)$ Mobile Learning; ( $n)$ Planning Committees; (o) Gamification; ( $p$ ) ProjectBased Learning; (q) Differentiated Instruction; (r) Professional Learning; (s) School Clubs; dan (t) Alumni Groups.

Dari uraian manfaat yang dapat diambil guru dengan menggunakan Edmodo, salah satunya adalah Workshop Pengembangan Profesi. Artinya bahwa Edmodo juga dapat dimanfaatkan oleh Pengawas Sekolah dalam mengembangkan profesionalitas guru binaannya.

Pengawas Sekolah bisa mengadopsi kegiatan e-Learning dengan menggunakan Edmodo untuk kegiatan-kegiatan pembimbingan guru dalam rangka meningkatkan profesionalitas guru. Salah satunya adalah membimbing guru dalam menyusun Proposal PTK. Pengawas Sekolah mengadopsi Edmodo sebagai sarana pembelajaran secara daring atau e-learning. Dalam hal ini Pengawas Sekolah bertindak sebagai guru, dan guru-guru binaan bertindak sebagai siswa.

Seperti pendapat Soekartawi (2012:199), e-learning memiliki karakteristik sebagai berikut: (1) memanfaatkan jasa teknologi elektronik, di mana guru dan siswa, siswa dan sesama siswa atau guru dan sesama guru dapat berkomunikasi dengan relatif mudah tanpa dibatasi oleh hal-hal yang protokoler; (2) memanfaatkan keunggulan komputer (digital media and computer networks); (3) menggunakan bahan ajar bersifat mandiri (self learning materials) yang disimpan di komputer sehingga dapat diakses oleh guru dan siswa kapan saja dan di mana saja bila yang bersangkutan memerlukan; dan (4) memanfaatkan jadwal pembelajaran, kurikulum, hasil kemajuan belajar, dan hal-hal yang berkaitan dengan administrasi pendidikan dapat dilihat setiap saat di komputer.

Edmodo sebagai salah satu bentuk teknologi pendidikan juga mempunyai manfaat seperti pendapat Kristanto (2016), yaitu: (1) teknologi pendidikan memungkinkan adanya perubahan kurikulum; (2) teknologi pendidikan menghilangkan, kalaupun tidak secara keseluruhan, pola pengajaran tradisional; (3) teknologi pendidikan membuat pengertian kegiatan-kegiatan belajar menjadi lebih luas; dan (4) aplikasi teknologi pendidikan dapat membuat peranan guru berkurang.

Selain keuntungan dan kemudahan dari Edmodo yang dapat digunakan oleh Pengawas Sekolah, tentunya ada juga kendala yang dihadapi dalam pelaksanannya. Salah satu kendalanya adalah gangguan dan belum stabil serta meratanya jaringan internet di Indonesia. Internet menjadi salah satu faktor pendukung terlaksananya kegiatan pembimbingan profesionalitas guru oleh Pengawas Sekolah dengan memanfaatkan Edmodo. Akan tetapi kenyataannya Internet masih menjadi kendala dalam pemanfaatan Edmodo, seperti fakta yang menyatakan bahwa kecepatan rata-rata akses Internet Indonesia memang belum bisa menyamai negara maju, karena pada kuartal pertama tahun 2016 masih berada di peringkat 94 dalam kawasan Asia Pasifik (cnnindonesia.com).

\section{Tugas Pokok Pengawas Sekolah}

Berdasarkan Peraturan Menteri Pendayagunaan Aparatur Negara No. 21 Tahun 2010 tentang Jabatan Fungsional Pengawas dan Angka Kreditnya, Pasal 5 menyebutkan bahwa tugas pokok Pengawas Sekolah adalah melaksanakan tugas pengawasan akademik dan manajerial pada 
satuan pendidikan yang meliputi penyusunan program pengawasan, pelaksanaan pembinaan, pemantauan pelaksanaan 8 (delapan) Standar Nasional Pendidikan, penilaian, pembimbingan dan pelatihan profesionalitas Guru, evaluasi hasil pelaksanaan program pengawasan, dan pelaksanaan tugas kepengawasan di daerah khusus.

Selain itu, Peraturan Menteri Pendidikan Nasional Nomor 12 Tahun 2012 tentang Kompetensi Pengawas Sekolah/Madrasah menyebutkan bahwa salah satu dimensi kompetensi yang harus dimiliki Pengawas Sekolah adalah dimensi kompetensi supervisi manajerial. Salah satu kompetensi dalam Kompetensi Supervisi Manajerial adalah mendorong guru dan kepala sekolah dalam merefleksikan hasil-hasil yang dicapainya untuk menemukan kelebihan dan kekurangan dalam melaksanakan tugas pokoknya di sekolah menengah yang sejenis. Salah satu bentuk tindakan refleksi yang dilakukan guru adalah melakukan PTK yang bertujuan untuk memperbaiki permasalahan yang ditemukan dalam proses pembelajaran yang dilakukannya. PTK adalah penelitian yang memaparkan terjadinya sebab akibat dari perlakuan, sekaligus memaparkan apa saja yang terjadi ketika perlakuan diberikan dan memaparkan seluruh proses sejak awal pemberian perlakuan sampai dengan dampak dari perlakuan yang diberikan kepada subjek tindakan (Arikunto, Suhardjono, Supardi, 2015: 4).

Pengawas Sekolah juga mempunyai tugas untuk melakukan supervisi akademik. Supervisi akademik yang dilakukan oleh Pengawas Sekolah mempunyai dampak yang sangat besar terhadap peningkatan kompetensi guru, yang pada akhirnya dapat meningkatkan mutu pembelajaran di sekolah. Supervisi dapat meningkatkan motivasi guru untuk melaksanakan tugas karena melalui supervisi, guru dapat meminta dukungan atau bantuan dari supervisor untuk perbaikan bagaimana sebaiknya guru tersebut melaksanakan pembelajaran di kelas. Keberadaan Pengawas Sekolah sebagai seorang supervisor benar-benar dibutuhkan guru, karena Pengawas Sekolah berperan sebagai sosok yang berperan besar dalam meningkatkan kompetensi guru, terutama dalam melaksanakan kegiatan pembelajaran di kelas.

Sejalan dengan kemajuan IImu Pengetahuan dan Teknologi, khususnya bidang TIK, Pengawas Sekolah dituntut untuk mampu memanfaatkan kemajuan TIK dalam melaksanakan tugas-tugas kepengawasannya, salah satunya adalah melakukan pembimbingan profesionalitas guru binaannya.

\section{Penelitian Tindakan Kelas (PTK)}

Penelitian tindakan merupakan suatu pencarian sistematik yang dilaksanakan para pelaksana program dalam kegiatannya sendiri (dalam pendidikan dilakukan oleh guru, dosen, kepala sekolah, konselor) dalam mengumpulkan data tentang pelaksanaan kegiatan, keberhasilan dan hambatan yang dihadapi, untuk kemudian menyusun rencana dan melakukan kegiatan-kegiatan penyempurnaan (Sukmadinata, 2015:140). Penelitian Tindakan Kelas (PTK) adalah penelitian yang berkaitan erat dengan proses pembelajaran yang diselenggarakan oleh guru di kelas. Kelas dalam hal ini adalah sekelompok murid atau rombongan pelajar dan guru yang sedang melakukan aktivitas pembelajaran (Tokan, 2016:53). PTK juga merupakan salah satu bagian dari tugas guru untuk melakukan perbaikan pembelajaran di kelas. Menurut Sanjaya (2016:11), PTK merupakan salah satu upaya yang dapat dilakukan guru untuk meningkatkan kualitas peran dan tanggung jawab guru khususnya dalam pengelolaan pembelajaran.

\section{Kompetensi Guru}

Kompetensi adalah kemampuan seseorang untuk melakukan pekerjaan atau tugas yang didasarkan pada keterampilan, pengetahuan, dan sikap yang didukung oleh pekerjaan sesuai dengan tuntutan pekerjaan, seperti pendapat yang mengatakan: "Competence is the ability of a person to exercise or perform a job or task that is based on skills, knowledge and attitudes supported 
by work in accordance with the demands of the job" (Hakim, 2015:3).

Ciri guru hebat seperti pendapat Orlando (2013) adalah: (1) A great teacher respects students; (2) A great teacher creates a sense of community and belonging in the classroom; (3) A great teacher is warm, accessible, enthusiastic and caring; (4) A great teacher sets high expectations for all students; (5) A great teacher has his own love of learning; (6) A great teacher is a skilled leader; (7) A great teacher can "shift-gears"; (8) A great teacher collaborates with colleagues on an ongoing basis; dan (9) A great teacher maintains professionalism in all areas.

Bila diterjemahkan, artinya adalah bahwa guru yang hebat itu memiliki ciri-ciri: (1) menghormati siswa; (2) menciptakan rasa memiliki kebersamaan dan rasa memiliki di dalam kelas; (3) hangat, mudah dihubungi, antusias dan peduli; (4) menetapkan harapan yang tinggi untuk semua siswa; (5) memiliki kecintaannya untuk belajar; (6) adalah pemimpin yang terampil; (7) bisa "memindahkan gigi"; (8) berkolaborasi dengan rekan kerja secara berkelanjutan; dan (9) memelihara profesionalisme di semua bidang.

Dalam Peraturan Menteri Pendidikan Nasional Republik Indonesia Nomor 16 Tahun 2007 Tentang Standar Kualifikasi Akademik dan Kompetensi Guru, disebutkan bahwa setiap guru wajib memenuhi standar kualifikasi akademik dan kompetensi guru yang berlaku secara nasional. Kompetensi guru meliputi empat kompetensi utama, yaitu kompetensi pedagogik, kepribadian, sosial, dan profesional. Keempat kompetensi tersebut terintegrasi dalam kinerja guru.

Kompetensi pedagogik meliputi: (1) menguasai karakteristik peserta didik dari aspek fisik, moral, sosial, kultural, emosional, dan intelektual; (2) menguasai teori belajar dan prinsip-prinsip pembelajaran yang mendidik; (3) mengembangkan kurikulum yang terkait dengan bidang pengembangan yang diampu; (4) menyelenggarakan kegiatan pengembangan yang mendidik; (5) memanfaatkan teknologi informasi dan komunikasi untuk kepentingan penyelenggaraan kegiatan pengembangan yang mendidik; (6) memfasilitasi pengembangan potensi peserta didik untuk mengaktualisasikan berbagai potensi yang dimiliki; (7) berkomunikasi secara efektif, empatik, dan santun dengan peserta didik; (8) menyelenggarakan penilaian dan evaluasi proses dan hasil belajar; (9) memanfaatkan hasil penilaian dan evaluasi untuk kepentingan pembelajaran; dan (10) melakukan tindakan reflektif untuk peningkatan kualitas pembelajaran.

Kompetensi Kepribadian meliputi: (1) bertindak sesuai dengan norma agama, hukum, sosial, dan kebudayaan nasional Indonesia; (2) menampilkan diri sebagai pribadi yang jujur, berakhlak mulia, dan teladan bagi peserta didik dan masyarakat; (3) menampilkan diri sebagai pribadi yang mantap, stabil, dewasa, arif, dan berwibawa; (4) menunjukkan etos kerja, tanggung jawab yang tinggi, rasa bangga menjadi guru, dan rasa percaya diri; dan (5) menjunjung tinggi kode etik profesi guru.

Kompetensi Sosial meliputi: (1) bersikap inklusif, bertindak objektif, serta tidak diskriminatif karena pertimbangan jenis kelamin, agama, ras, kondisi fisik, latar belakang keluarga, dan status sosial ekonomi; (2) berkomunikasi secara efektif, empatik, dan santun dengan sesama pendidik, tenaga kependidikan, orang tua, dan masyarakat; (3) beradaptasi di tempat bertugas di seluruh wilayah Republik Indonesia yang memiliki keragaman sosial budaya; dan (4) berkomunikasi dengan komunitas profesi sendiri dan profesi lain secara lisan dan tulisan atau bentuk lain.

Kompetensi Profesional meliputi: (1) menguasai materi, struktur, konsep, dan pola pikir keilmuan yang mendukung mata pelajaran yang diampu; (2) menguasai standar kompetensi dan kompetensi dasar mata pelajaran/bidang pengembangan yang diampu; (3) mengembangkan materi pembelajaran yang diampu secara kreatif; (4) mengembangkan keprofesionalan secara berkelanjutan dengan melakukan tindakan reflektif; dan (5) memanfaatkan teknologi informasi dan komunikasi untuk berkomunikasi dan mengembangkan diri. 
Pada saat sekarang, di mana kemajuan TIK sudah berkembang dengan sangat pesat, guru sebagai agent of change dituntut untuk senantiasa berusaha menguasai TIK yang dapat dimanfaatkan untuk membantu pelaksanaan tugas pembelajaran di kelas. Diakui atau tidak, pengintegrasian TIK dalam pembelajaran akan mendukung kemampuan siswa dan memberikan arti bagi mereka, seperti pendapat yang mengatakan: "ICT enables self-paced learning through various tools such as assignment, computer, etc. as a result of this the teaching learning enterprise has become more productive and meaningful. ICT helps facilitate the transaction between producers and users by keeping the students updated and enhancing teacher's capacity and ability fostering a live contact between the teacher and the student (Sharma, Gandhar, Seema, 2011:1)". Artinya, adalah bahwa TIK memungkinkan pembelajaran mandiri melalui berbagai alat seperti penugasan, komputer, dan lain-lain sebagai akibatnya usaha pembelajaran ini menjadi lebih produktif dan bermakna. TIK membantu memfasilitasi transaksi antara produsen dan pengguna dengan menjaga agar siswa diperbarui dan meningkatkan kapasitas dan kemampuan guru untuk membina kontak langsung antara guru dan siswa.

Penguasaan TIK dalam proses pembelajaran di kelas adalah salah satu kompetensi yang diharapkan dikuasai tenaga pendidik, seperti yang diamanatkan oleh UU Nomor 14 Tahun 2005 tentang Guru dan Dosen. Dalam UU tersebut disebutkan bahwa "Kompetensi TIK guru adalah kemampuan guru dalam mengembangkan inovasi pembelajaran dengan memanfaatkan TIK, baik dalam merencanakan, melaksanakan, maupun mengevaluasi pembelajaran, baik pada domain kompetensi pedagogik, personal, profesional, maupun sosial".

Salah satu kompetensi yang harus dimiliki guru adalah Kompetensi Profesional. Salah satu indikator dalam Kompetensi Profesional adalah bahwa guru harus mampu mengembangkan keprofesionalan secara berkelanjutan dengan melakukan tindakan reflektif, termasuk di dalamnya melakukan PTK. Agar guru mampu memenuhi tuntutan tersebut, Pengawas Sekolah bertanggung jawab untuk membimbing guru agar mampu melakukan PTK, di mana salah satu langkah untuk melakukan PTK adalah menyusun Proposal PTK. Untuk membimbing guru agar mampu menyusun Proposal PTK, Pengawas Sekolah dapat memanfaatkan media daring dengan menggunakan platform Edmodo.

Pemanfaatan Edmodo dalam pembimbingan ini dipilih karena pembimbingan secara online dapat mempercepat pemahaman teori dan konsep seperti pendapat yang mengatakan bahwa melalui tutorial dalam jaringan (daring) atau online, banyak jenis media yang dapat diberikan kepada mahasiswa guna mempercepat pemahaman teori dan konsep. (Susanti, Halimah, Harta, Karyana, 2018).

\section{Pemanfaatan Edmodo dalam Pembimbingan Guru Menyusun Proposal PTK oleh Pengawas Sekolah}

\section{Tahap Persiapan}

Tahap pertama untuk melakukan pembimbingan guru dengan menggunaan Edmodo, tentunya Pengawas Sekolah harus memiliki akun di Edmodo. Kegiatan selanjutnya adalah melakukan pertemuan awal dengan guru-guru PJOK secara tatap muka (offline) untuk memperkenalkan Edmodo, cara membuat akun Edmodo, mengenal fitur-fitur di Edmodo, cara mengikuti kelas atau grup di Edmodo, cara mengerjakan kuis, dan cara mengirimkan tugas atau mengunggah file di Edmodo.

Untuk masuk ke Edmodo, Pengawas Sekolah pertama-tama mengetikkan Edmodo di mesin pencari atau web browser, kemudian klik dan akan muncul hasil pencarian Edmodo. Atau bisa langsung mengetikkan www.edmodo.com. Setelah itu, akan muncul halaman awal dari Edmodo seperti pada Gambar berikut ini. 
Sumarso: Pemanfaatan Edmodo oleh Pengawas Sekolah dalam Membimbing Guru Menyusun Proposal Penelitian Tindakan Kelas

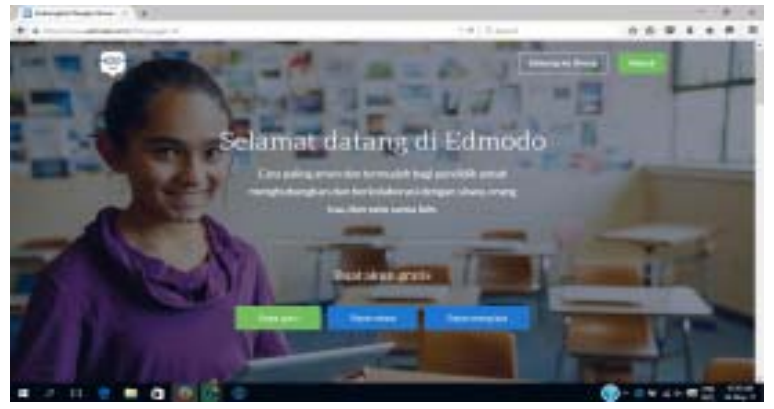

Gambar 1: Halaman Awal Edmodo Sumber: https://www.edmodo.com ?language=id diakses: 20 Mei 2017

Setelah memiliki akun Edmodo, Pengawas melakukan Log-in dengan mengklik menu Masuk, dan setelah itu akan dibawa ke halaman Log-in. Gambar tampilan Log-in pada Edmodo dapat dilihat pada Gambar di bawah ini.

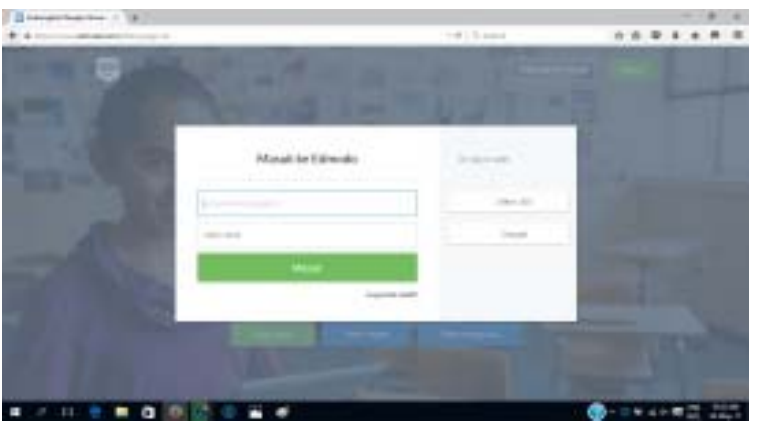

Gambar 2: Halaman Log-in di Edmodo Sumber:https://www.edmodo.com/? language= id diakses: 20 Mei 2017

Pengawas Sekolah mengetikkan alamat email dan password yang telah digunakan untuk mendaftarkan akun di Edmodo. Setelah berhasil masuk di akun Edmodo, akan muncul halaman beranda Edmodo, seperti pada Gambar berikut ini.

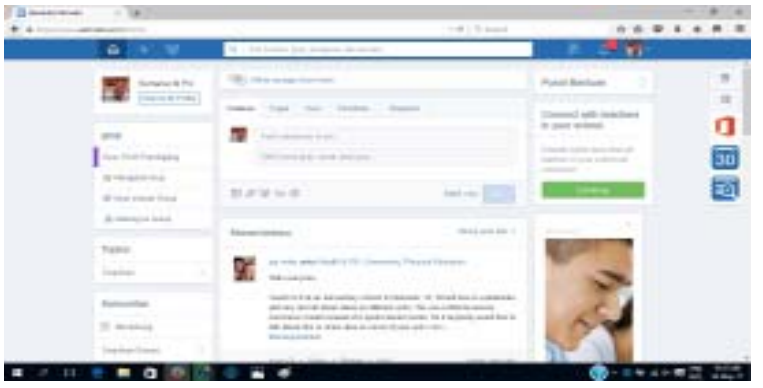

Gambar 3: Halaman Beranda Edmodo Sumber: https://www.edmodo.com/home diakses: 20 Mei 2017
Setelah berhasil masuk ke Edmodo, langkah selanjutnya, Pengawas Sekolah membuat kelas atau grup yang akan digunakan sebagai tempat pembimbingan guru. Langkah membuat kelas atau grup di Edmodo adalah, sebagai berikut.

Pada halaman beranda Edmodo, klik menu Buat Kelas, kemudian akan muncul format isian nama kelas, rentang atau jenjang kelas. Karena Pengawas Sekolah menggunakan kelas ini untuk para guru, bisa kita pilih kelasnya tidak ada. Kemudian pilih subyek atau bidang studi. Karena Pengawas menggunakan kelas yang dibuat untuk kegiatan pembimbingan guru, Pengawas memilih Pengembangan Profesi. Karena pada kegiatan pembimbingan guru yang dilakukan Pengawas Sekolah sasarannya adalah guru PJOK, kelas diberi nama PJOK Pandeglang. Gambar tampilan kelas, dapat dilihat pada Gambar berikut ini.

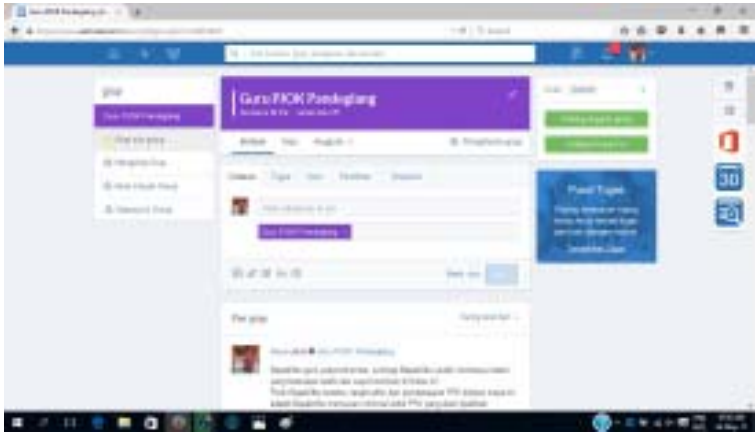

Gambar 4: Tampilan Kelas Guru PJOK Pandeglang Sumber: https://www.edmodo.com/home\#/ group?id=23803647 diakses: 20 Mei 2017

Setelah dibuat kelas, kita bisa mengetahui kode kelas yang telah dibuat. Kode kelas tersebut dibagikan kepada Guru-Guru PJOK SMP di Kabupaten Pandeglang untuk dapat masuk di Kelas tersebut. Undangan untuk bergabung di Kelas PJOK, disampaikan melalui SMS, WhatsApp, maupun E-Mail. Setelah undangan disebar, ternyata tergabung sebanyak 20 orang guru PJOK SMP dari seluruh wilayah Kabupaten Pandeglang.

Setelah siswa atau anggota kelas sudah ada, selanjutnya Pengawas membuat tawaran materi yang akan dipelajari atau menjadi materi pembimbingan guru. Langkah 
Sumarso: Pemanfaatan Edmodo oleh Pengawas Sekolah dalam Membimbing Guru Menyusun Proposal Penelitian Tindakan Kelas

selanjutnya adalah membuat pooling, dengan cara meng-klik menu pemilihan di halaman kelas. Tampilan pooling dapat dilihat di bawah ini.

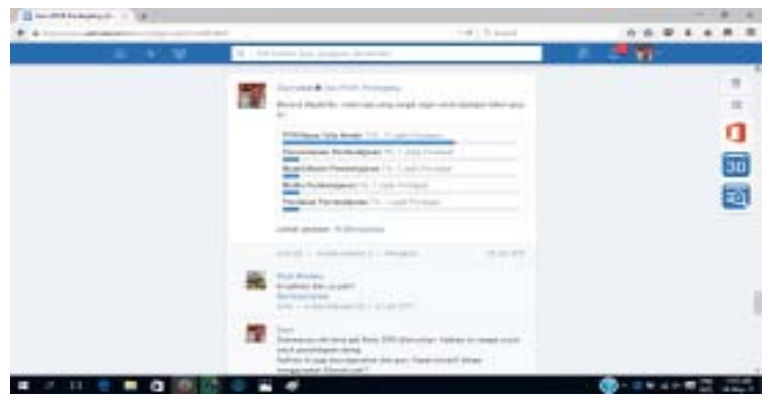

Gambar 5: Pooling atau Jajak Pendapat untuk Memilih Materi Pembimbingan

Sumber: https://www.edmodo.com/home\#/ group?id=23803647diakses: 25 Mei 2017

Setelah diadakan pooling ternyata dari 20 guru didapatkan 14 orang guru (73\%) memilih materi PTK. Sehingga Pengawas Sekolah selanjutnya mempersiapkan materi-materi tentang PTK, khususnya tentang penyusunan Proposal PTK. Setelah Kelas terbentuk, guru peserta pembimbingan telah didapatkan, dan materi pembimbingan telah disepakati, selanjutnya masuk ke tahap pelaksanaan pembimbingan guru dengan menggunakan Edmodo.

\section{Tahap Pelaksanaan}

Pelaksanaan pembimbingan guru selanjutnya dilakukan secara daring (online) dengan memanfaatkan Edmodo, khususnya untuk Kelas Guru PJOK dengan Materi Penelitian Tindakan Kelas. Pengawas yang bertindak sebagai guru menyampaikan materi-materi pada catatan atau memberikan materi di Library yang dapat diakses oleh guru-guru yang menjadi anggota kelas.

Pengawas dan guru berkomunikasi melalui Edmodo. Kegiatan Pembimbingan dilakukan dalam rentang satu bulan, tanggal 15 Mei 2017 s.d. 10 Juni 2017. Sedangkan jumlah pertemuan tidak bisa diketahui secara pasti, karena guru bisa mengakses materi pembimbingan di Edmodo kapan saja dan di mana saja. Contoh komunikasi atau respons dari guru dapat dilihat pada Gambar berikut.

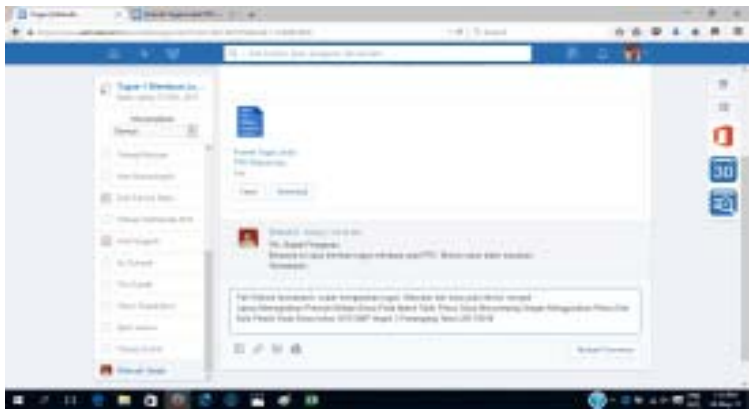

Gambar 6: Respon Guru Terhadap Tugas dari Pengawas

Sumber: https://www.edmodo.com/home\# assigment mid $=641681836 \&$ uid $=124983606$ diakses: 29 Mei 2017

Pada pelaksanaan pembimbingan guru melalui Edmodo, Pengawas memberikan materi-materi pembimbingan berupa tayangan video, powerpoint, pdf, maupun LKLK yang harus dikerjakan guru. Pengawas Sekolah memberikan soal-soal latihan dengan memanfaatkan fitur soal yang disediakan di Edmodo, seperti soal pilihan ganda, soal jawaban singkat, soal menjodohkan, soal benar salah, maupun soal berupa format untuk mengisi rancangan judul PTK yang direncanakan akan dilakukan sebagai sebuah PTK. Contoh soal-soal latihan yang diberikan Pengawas untuk dikerjakan oleh guru, dapat dilihat pada Gambar-gambar berikut.

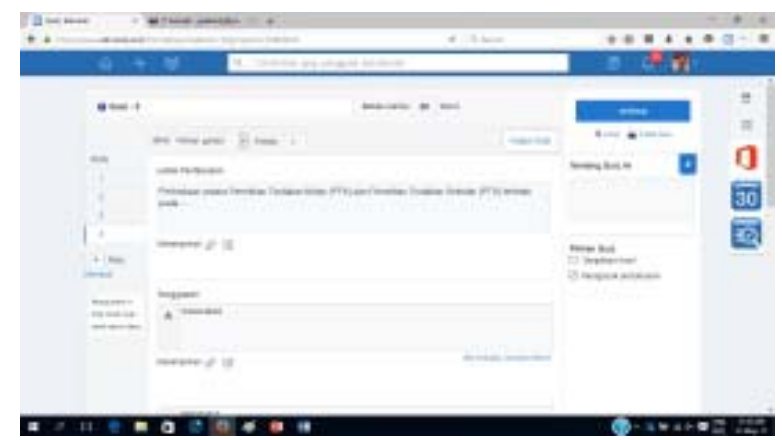

Gambar 7: Membuat Soal Pilihan Ganda

Sumber: https://www.edmodo.com/home\#/ quiz?referrer=\#group?id=23803647 diakses: 1 Juni 2017 
Sumarso: Pemanfaatan Edmodo oleh Pengawas Sekolah dalam Membimbing Guru Menyusun Proposal Penelitian Tindakan Kelas

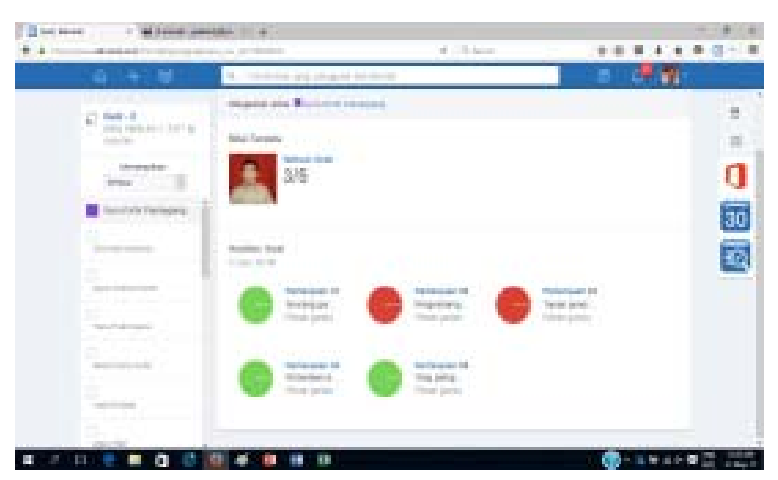

Gambar 8: Contoh Jawaban Pilihan Ganda dari Guru

Sumber: https://www.edmodo.com/home\#/quiz/grade/ quiz_run_id/13954000 diakses: 1 Juni 2017

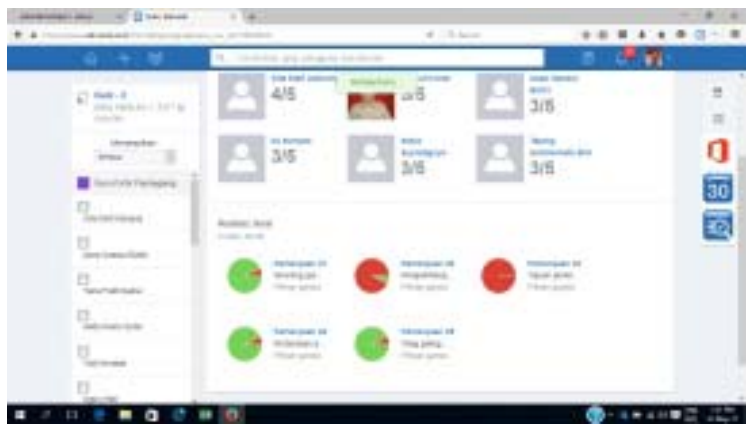

Gambar 9: Analisis Pilihan Ganda

Sumber: https://www.edmodo.com/home\#/quiz/grade/ quiz_run_id/13954000. diakses: 5 Juni 2017

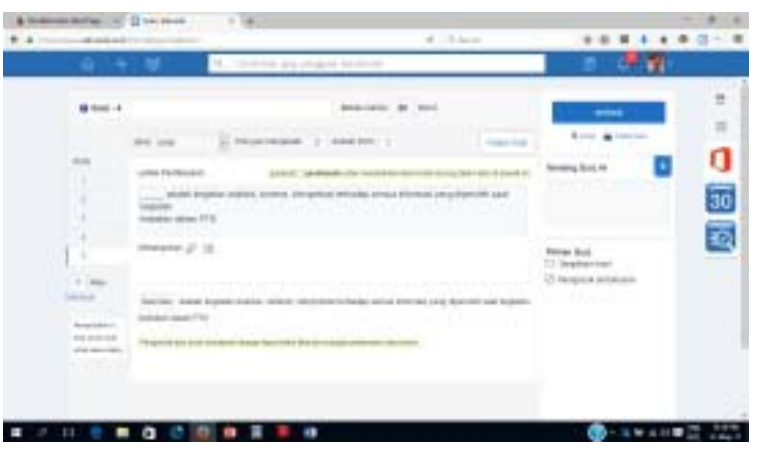

Gambar 10: Membuat Soal Uraian

Sumber: https://www.edmodo.com/home\#/quiz?referrer= diakses: 5 Juni 2017

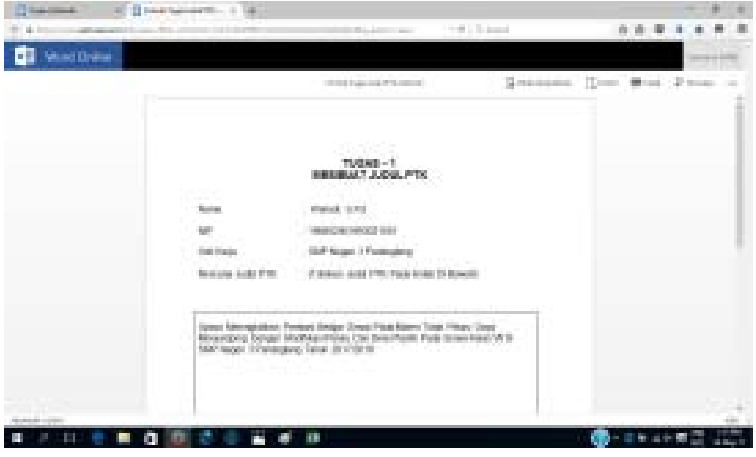

Gambar 11: Contoh Tugas Guru Membuat Judul PTK

Sumber: https://www.edmodo.com/file/view-officeonline?id= diakses: 5 Juni 2017

Semua tugas maupun soal-soal atau quiz bisa dibuat deadline atau batas akhir pengerjaan, sehingga melalui kegiatan ini guru juga dituntut untuk disiplin dalam mengerjakan tugas-tugas yang diberikan Pengawas Sekolah.

\section{Tahap Penilaian}

Selama kegiatan pembimbingan guru, Pengawas Sekolah melakukan penilaian terhadap aktivitas guru seperti, keaktifan mengajukan pertanyaan maupun tanggapan dari pertanyaan sesama guru. Penilaian juga didasarkan pada respons atau jawabanjawaban terhadap soal atau quiz yang diberikan Pengawas Sekolah. Hasil penilaian dapat dilihat pada Gambar di bawah ini.

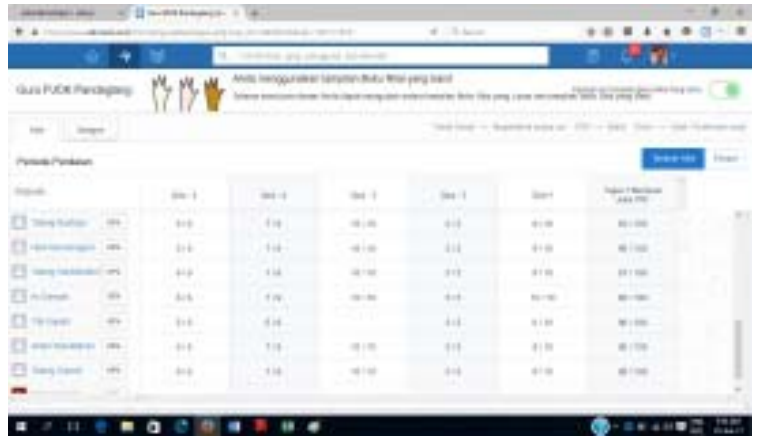

Gambar 12

Hasil Penilaian Guru oleh Pengawas

Sumber: https://www.edmodo.com/home\#/gradebook/ group?group_id= diakses: 10 Juni 2017 
Sumarso: Pemanfaatan Edmodo oleh Pengawas Sekolah dalam Membimbing Guru Menyusun Proposal Penelitian Tindakan Kelas

Pengawas dapat mengekspor nilai guruguru kedalam format Excell, seperti pada Gambar di bawah ini.

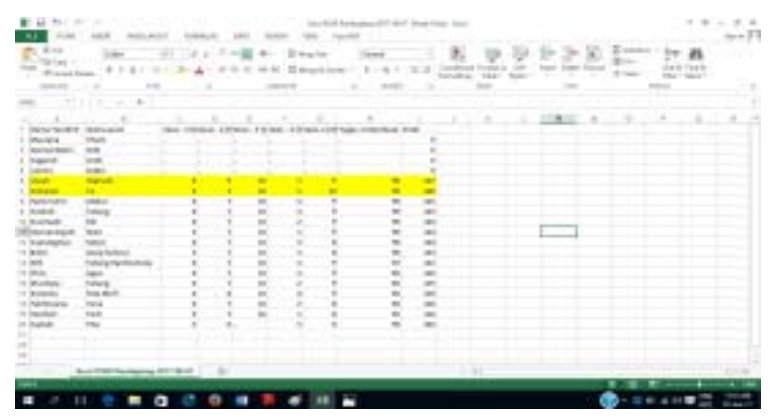

Gambar 13: Nilai Guru dalam Format Excell

Penilaian yang dilakukan oleh Pengawas terhadap guru dalam kegiatan pembimbingan melalui Edmodo, meliputi penilaian proses, penilaian kuis, dan penilaian produk. Penilaian proses meliputi: (1) keaktifan peserta mengakses Edmodo; (2) keaktifan peserta menanggapi postingan yang diberikan oleh pengawas; (3) keaktifan peserta menanggapi postingan peserta lain; dan (4) keaktifan peserta memberikan jawaban/solusi atas pertanyaan yang diposting peserta lain. Penilaian produk meliputi hasil penilaian atau kuis yang diposting di Edmodo yang menggambarkan pemahaman guru tentang PTK.

Selain itu, penilaian produk yang dilakukan adalah menilai tugas yang diunggah peserta di Edmodo berupa file proposal PTK. Sistematika proposal PTK menurut Arikunto (2015) adalah: (1) Judul Penelitian; (2) Pendahuluan; (3) Kajian Pustaka; (4) Metodologi Penelitian; (5) Jadwal Pelaksanaan; dan (6) Daftar Pustaka.
Tabel 1. Format Daftar Nilai Proses

\begin{tabular}{lllll} 
No. Guru & \multicolumn{1}{l}{ Aspek / Skor } \\
\cline { 2 - 4 } & $\begin{array}{lllll}4 & 3 & 2 & 1\end{array} \quad$ Nilai
\end{tabular}

Keterangan Aspek:

1. Keaktifan peserta mengakses Edmodo;

2. Keaktifan peserta menanggapi postingan yang diberikan pengawas;

3. Keaktifan peserta menanggapi postingan peserta lain;

4. Keaktifan peserta memberikan jawaban/solusi atas pertanyaan yang diposting peserta lain.

Keterangan Skor:

4. Selalu; 3. Sering; 2. Kadang-kadang; 1 . Tidak Pernah

Tabel 2. Daftar Nilai Proses

\begin{tabular}{|c|c|c|c|c|c|c|}
\hline \multicolumn{2}{|r|}{ No. Guru } & \multicolumn{4}{|c|}{ Aspek / Skor } & \multirow[t]{2}{*}{ Nilai } \\
\hline & & 4 & 3 & 2 & 1 & \\
\hline 1 & Guru 1 & & 3 & & & 75 \\
\hline 2 & Guru 2 & & 3 & & & 75 \\
\hline 3 & Guru 3 & & 4 & & & 100 \\
\hline 4 & Guru 4 & & 3 & & & 75 \\
\hline 5 & Guru 5 & & & 2 & & 50 \\
\hline 6 & Guru 6 & & 3 & & & 75 \\
\hline 7 & Guru 7 & 4 & & & & 100 \\
\hline 8 & Guru 8 & & & 2 & & 50 \\
\hline 9 & Guru 9 & & & 2 & & 50 \\
\hline 10 & Guru 10 & & 3 & & & 75 \\
\hline 11 & Guru 11 & & & 2 & & 50 \\
\hline 12 & Guru 12 & 4 & & & & 100 \\
\hline 13 & Guru 13 & & & 2 & & 50 \\
\hline 14 & Guru 14 & & 3 & & & 75 \\
\hline 15 & Guru 15 & & 3 & & & 75 \\
\hline 16 & Guru 16 & & 3 & & & 75 \\
\hline 17 & Guru 17 & 4 & & & & 100 \\
\hline 18 & Guru 18 & & 3 & & & 75 \\
\hline 19 & Guru 19 & & 3 & & & 75 \\
\hline 20 & Guru 20 & & & & 1 & 25 \\
\hline
\end{tabular}


Sumarso: Pemanfaatan Edmodo oleh Pengawas Sekolah dalam Membimbing Guru Menyusun Proposal Penelitian Tindakan Kelas

Tabel 3. Format Daftar Nilai Kuis

\begin{tabular}{llllllll}
\hline No. Guru & \multicolumn{4}{c}{ Jenis Kuis / Nilai } & Rerata \\
\cline { 2 - 5 } & 1 & 2 & 3 & 4 & 5 & \\
\hline
\end{tabular}

Keterangan Jenis Kuis:

1. Pilihan Ganda,

2. Benar Salah,

3. Menjodohkan,

4. Uraian,

5. Melengkapi Jawaban.

Tabel 4 Daftar Nilai Kuis

\begin{tabular}{llllll}
\hline \multirow{2}{*}{ No. Guru } & \multicolumn{4}{l}{ Jenis Kuis / Nilai } \\
\cline { 2 - 5 } & 1 & 2 & 3 & 4 & 5
\end{tabular}

$1 \begin{array}{llllllll}1 & \text { Guru 1 } & 80 & 85 & 75 & 85 & 80 & 81\end{array}$

$2 \begin{array}{llllllll} & \text { Guru } 2 & 95 & 90 & 85 & 80 & 75 & 85\end{array}$

$3 \begin{array}{llllllll}3 & \text { Guru } 3 & 75 & 75 & 80 & 80 & 80 & 78\end{array}$

$4 \begin{array}{llllllll}4 & \text { Guru } 4 & 80 & 75 & 75 & 80 & 75 & 77\end{array}$

$\begin{array}{llllllll}5 & \text { Guru } 5 & 80 & 80 & 80 & 75 & 80 & 79\end{array}$

$6 \begin{array}{llllllll}6 & \text { Guru } 6 & 80 & 90 & 90 & 85 & 75 & 84\end{array}$

$\begin{array}{llllllll}7 & \text { Guru } 7 & 80 & 80 & 80 & 80 & 75 & 79\end{array}$

$8 \begin{array}{llllllll}8 & \text { Guru } 8 & 90 & 75 & 80 & 80 & 90 & 83\end{array}$

$9 \begin{array}{llllllll}9 & \text { Guru } 9 & 90 & 75 & 80 & 80 & 80 & 81\end{array}$

10 Guru $\begin{array}{lllllll}10 & 85 & 80 & 80 & 85 & 85 & 83\end{array}$

11 Guru $11 \quad 80 \quad 80 \quad 75 \quad 90 \quad 85 \quad 82$

12 Guru $12 \quad 85 \quad 90 \quad 75 \quad 75 \quad 85 \quad 82$

13 Guru $13 \quad 75 \quad 90 \quad 80 \quad 75 \quad 70 \quad 78$

14 Guru $14 \quad 75 \quad 85 \quad 85 \quad 75 \quad 75 \quad 79$

15 Guru $15 \quad 75 \quad 80 \quad 85 \quad 75 \quad 80 \quad 79$

16 Guru $16 \quad 80 \quad 80 \quad 85 \quad 70 \quad 85 \quad 80$

17 Guru $17 \quad 85 \quad 90 \quad 85 \quad 80 \quad 85 \quad 85$

18 Guru $18 \quad 90 \quad 85 \quad 80 \quad 80 \quad 85 \quad 84$

19 Guru $19 \quad 90 \quad 80 \quad 80 \quad 75 \quad 80 \quad 81$

20 Guru $20 \quad 80 \quad 75 \quad 80 \quad 70 \quad 75 \quad 76$

Tabel 5. Format Daftar Nilai Produk

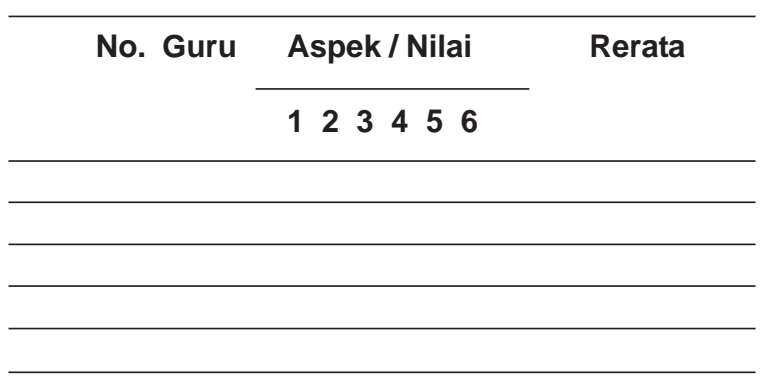

Keterangan Aspek:

1. Judul Penelitian,

2. Pendahuluan,

3. Kajian Pustaka,

4. Metodologi Penelitian,

5. Jadwal Pelaksanaan,

6. Daftar Pustaka.

Tabel 6. Daftar Nilai Produk

\begin{tabular}{|c|c|c|c|c|c|c|c|}
\hline \multirow[t]{2}{*}{ No. Guru } & \multicolumn{6}{|c|}{ Aspek / Nilai } & \multirow[t]{2}{*}{ Rerata } \\
\hline & 1 & 2 & 3 & 4 & 5 & 6 & \\
\hline 1 Guru 1 & 90 & 85 & 90 & 80 & 80 & 85 & 85 \\
\hline 2 Guru 2 & 90 & 85 & 90 & 80 & 80 & 85 & 85 \\
\hline 3 Guru 3 & 90 & 80 & 90 & 80 & 90 & 85 & 86 \\
\hline 4 Guru 4 & 90 & 80 & 90 & 85 & 90 & 85 & 87 \\
\hline 5 Guru 5 & 90 & 85 & 80 & 85 & 90 & 80 & 85 \\
\hline 6 Guru 6 & 90 & 90 & 85 & 80 & 90 & 80 & 86 \\
\hline 7 Guru 7 & 85 & 90 & 80 & 80 & 85 & 90 & 85 \\
\hline 8 Guru 8 & 80 & 85 & 90 & 85 & 80 & 85 & 84 \\
\hline 9 Guru 9 & 85 & 85 & 90 & 90 & 80 & 85 & 86 \\
\hline 10 Guru 10 & 90 & 85 & 85 & 90 & 85 & 85 & 87 \\
\hline 11 Guru 11 & 90 & 80 & 85 & 85 & 85 & 85 & 85 \\
\hline 12 Guru 12 & 90 & 80 & 85 & 85 & 85 & 80 & 84 \\
\hline 13 Guru 13 & 95 & 80 & 90 & 85 & 85 & 80 & 86 \\
\hline 14 Guru 14 & 90 & 80 & 85 & 85 & 85 & 90 & 86 \\
\hline 15 Guru 15 & 85 & 75 & 85 & 80 & 85 & 80 & 82 \\
\hline 16 Guru 16 & 85 & 75 & 80 & 80 & 85 & 80 & 81 \\
\hline 17 Guru 17 & 80 & 80 & 80 & 80 & 90 & 80 & 82 \\
\hline 18 Guru 18 & 90 & 80 & 85 & 85 & 90 & 85 & 86 \\
\hline 19 Guru 19 & 85 & 80 & 85 & 85 & 85 & 90 & 85 \\
\hline 20 Guru 20 & 90 & 85 & 80 & 85 & 85 & 85 & 85 \\
\hline
\end{tabular}

Tabel 7. Format Daftar Nilai

\begin{tabular}{|c|c|c|c|c|c|}
\hline \multirow[t]{2}{*}{ No. } & \multirow[t]{2}{*}{ Guru } & \multicolumn{3}{|c|}{ Jenis Kuis / Nilai } & \multirow[t]{2}{*}{ Rerata } \\
\hline & & 1 & 2 & 3 & \\
\hline
\end{tabular}

$\begin{array}{llrrrr}1 & \text { Guru 1 } & 75 & 81 & 85 & 80.33 \\ 2 & \text { Guru 2 } & 75 & 85 & 85 & 81.67 \\ 3 & \text { Guru 3 } & 100 & 78 & 86 & 88.00 \\ 4 & \text { Guru 4 } & 75 & 77 & 87 & 79.67 \\ 5 & \text { Guru 5 } & 50 & 79 & 85 & 71.33 \\ 6 & \text { Guru 6 } & 75 & 84 & 86 & 81.67 \\ 7 & \text { Guru 7 } & 100 & 79 & 85 & 88.00 \\ 8 & \text { Guru 8 } & 50 & 83 & 84 & 72.33 \\ 9 & \text { Guru 9 } & 50 & 81 & 86 & 72.33 \\ 10 & \text { Guru 10 } & 75 & 83 & 87 & 81.67\end{array}$




\begin{tabular}{llllll}
\hline 11 & Guru 11 & 50 & 82 & 85 & 72.33 \\
12 & Guru 12 & 100 & 82 & 84 & 88.67 \\
13 & Guru 13 & 50 & 78 & 86 & 71.33 \\
14 & Guru 14 & 75 & 79 & 86 & 80.00 \\
15 & Guru 15 & 75 & 79 & 82 & 78.67 \\
16 & Guru 16 & 75 & 80 & 81 & 78.67 \\
17 & Guru 17 & 100 & 85 & 82 & 89.00 \\
18 & Guru 18 & 75 & 84 & 86 & 81.67 \\
19 & Guru 19 & 75 & 81 & 85 & 80.33 \\
20 & Guru 20 & 25 & 76 & 85 & 62.00 \\
\hline \multicolumn{7}{c}{ Rerata } & $\mathbf{7 1 . 2 5}$ & $\mathbf{8 0 . 8 0}$ & $\mathbf{8 4 . 9 0}$ & $\mathbf{7 8 . 9 8}$
\end{tabular}

Keterangan Jenis Penilaian
1. Nilai Proses
2. Nilai Pengetahuan/Kuis
3. Nilai Produk (Proposal PTK)

Daftar perolehan nilai pembimbingan masing-masing guru yang terdiri atas nilai proses, nilai kuis, nilai produk, dan rata-rata nilai dapat digambarkan pada Grafik di bawah ini:

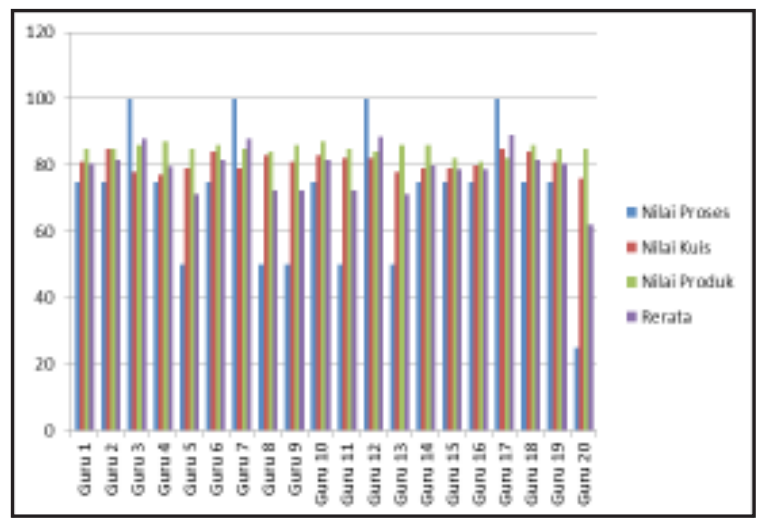

Gambar 15: Grafik Perolehan Nilai dan Rata-Rata Nilai

Apabila dilihat dari rata-rata nilai masingmasing aspek penilaian yaitu penilaian proses, penilaian kuis, dan penilaian produk, tampilannya dapat dilihat pada Grafik berikut.

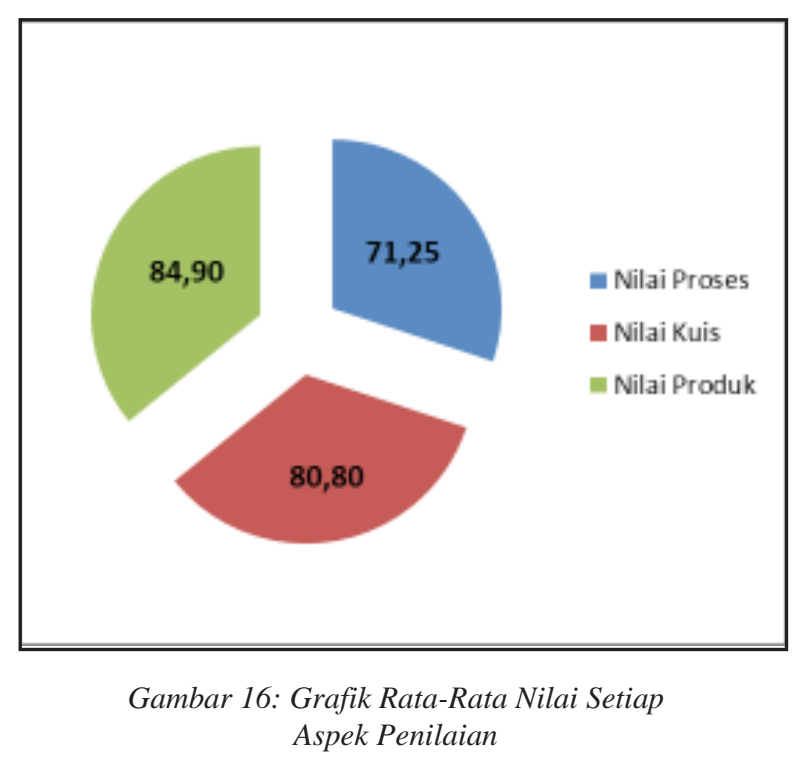

\section{SIMPULAN DAN SARAN}

\section{Simpulan}

Pada akhirnya, efektivitas pemanfaatan TIK oleh Pengawas Sekolah seperti pemanfaatan Edmodo untuk pembimbingan profesionalitas guru juga bergantung kepada tersedianya jaringan internet yang bagus dan kuat. Tetapi fakta yang ada bahwa kondisi jaringan internet di Indonesia belum merata dan masih kalah cepat dengan negaranegara lain.

Namun demikian, apabila semua pihak yang terkait saling bersinergi dan mempunyai komitmen yang sama untuk memajukan pengembangan TIK di Indonesia, pemanfaatan TIK Pengawas Sekolah dalam rangka optimalisasi pelaksanaan tugas-tugas kepengawasan khususnya dalam meningkatkan profesionalitas guru di zaman kemajuan TIK dapat terlaksana dengan baik.

Salah satu kemajuan bidang TIK yang dapat digunakan Pengawas Sekolah dalam membimbing profesionalitas guru adalah Edmodo.

\section{Saran}

Melalui artikel ini, penulis ingin memberikan saran kepada Pengawas Sekolah bahwa sebagai Pengawas Sekolah yang memiliki peranan sangat strategis dalam membimbing dan membina guru untuk 
menjadi profesional, hendaknya Pengawas Sekolah senantiasa meng-update diri dan melakukan pengembangan keprofesian berkelanjutan menyesuaikan dengan perkembangan ilmu pengetahuan dan teknologi, khususnya kemajuan di bidang TIK.

Penulis juga ingin memberikan saran kepada Dinas Pendidikan dan Kebudayaan agar sebagai instansi Pembina Pengawas Sekolah, Dinas Pendidikan dan Kebudayaan hendaknya memfasilitasi Pengawas Sekolah untuk melakukan kegiatan pengembangan keprofesian berkelanjutan seperti kegiatan Penguatan Pengawas Sekolah, dengan materi-materi yang substansial dengan tupoksi Pengawas Sekolah, memberdayakan Pengawas Sekolah terutama dalam kemampuan penguasaan TIK sebagai penunjang dalam pelaksanaan tugas-tugas kepengawasan.

Kepada Direktorat Pembinaan Tenaga Kependidikan Pendidikan Dasar dan Menengah Direktorat Jenderal Guru dan Tenaga Kependidikan Kementerian Pendidikan dan Kebudayaan sebagai instansi di pusat yang menaungi dan bertanggung jawab terhadap pembinaan karir Pengawas Sekolah, diharapkan selalu memberikan bantuan terutama bantuan berupa Block Grant kepada Musyawarah Kerja Pengawas Sekolah (MKPS) sebagai komunitas pendidikan yang bertanggung jawab terhadap peningkatan mutu pendidikan di sekolah, untuk melakukan kegiatan-kegiatan pengembangan keprofesian berkelanjutan dalam wadah MKPS.

Selain itu, penulis juga ingin memberikan saran kepada Pusat Data dan Teknologi Informasi (PUSDATIN) Kemendikbud agar mengadakan kegiatan pelatihan atau bimtek kepada Pengawas Sekolah berkaitan dengan pemanfaatan Teknologi Informasi dan Komunikasi sebagai penunjang dalam tugastugas kepengawasan, karena sampai saat ini belum pernah ada pelatihan bagi Pengawas Sekolah tentang pemanfaatan TIK untuk menunjang pelaksanaan tugas-tugas kepengawasan.

\section{PUSTAKA ACUAN}

20 Ways-to-Use-Edmodo- Teacher. (2017). https:/ /support.edmodo.com/hc/en-us/articles/ 205007974.

Andoh Charles, B. (2012). Factors influencing teachers ' adoption and integration of information and communication technology into teaching/: A review of the literature. International Journal of Education and Development using Information and Communication Technology, 8(1), 136-155.

Arikunto, S., Suhardjono, \& Supardi. (2015). Penelitian Tindakan Kelas Edisi Revisi. Bumi Aksara.

Dwiharja, M., \& Laksmi. (2015). Memanfaatkan Edmodo Sebagai Media Pembelajaran Akuntansi. Prosiding Seminar Nasional $9 \mathrm{Mei}$ 2015. 332-344.

Hakim, A. (2015). Contribution of Competence Teacher (Pedagogical, Personality, Professional Competence and Social) On the Performance of Learning. The International Journal Of Engineering And Science, 4(2), 112. www.theijes.com.

Kristanto, A. (2016). Aplikasi teknologi pendidikan di sekolah. Jurnal Teknologi Pendidikan, 4, 13-16.

Kumar, B. A., \& Sharma, B. (2020). Context aware mobile learning application development: $\mathrm{A}$ systematic literature review. Education and Information Technologies, 25(3), 2221-2239. https://doi.org/10.1007/s10639-019-10045-x.

Marzal, J. (2014). Studi Penggunaan Jejaring Sosial Edmodo yang Tidak Terbiasa Bekerja dengan Komputer. Edimatica, 4(1), 37-43.

Muliawan, J. U. (2014). Metodologi Penelitian Pendidikan. Gava Media.

Nassaji, H. (2015). Qualitative and Descriptive Research: Data Type Versus Data Analysis. https://www.researchgate.net/ publication/ 276397426.

Peraturan Menteri Pendayagunaan Aparatur Negara dan Reformasi Birokrasi RI Nomor 21 Tahun 2010 tentang Jabatan Fungsional Pengawas Sekolah dan Angka Kreditnya, Pub. L. No. 21 (2010).

Orlando, M. (2017). Nine Characteristics of a Great Teacher. https://www.facultyfocus.com/ 
articles/philosophy-of-teaching/ninecharacteristics-of-a-great-teacher/\#sthash. dXMc6QbB.dpuf.

Peraturan Menteri Pendidikan Nasional RI Nomor 16 Tahun 2007 tentang Standar Kualifikasi Akademik dan Kompetensi Guru, Pub. L. No. 16 (2007).

Peraturan Menteri Pendidikan Nasional RI Nomor 12 Tahun 2012 tentang Kompetensi Pengawas Sekolah/Madrasah, Pub. L. No. 12 (2012).

Sanjaya, W. (2016). Penelitian Tindakan Kelas. Kencana.

Shuttleworth, M. (2019). Descriptive Research Design. https://explorable.com/ descriptiveresearch-design.

Soekartawi. (2012). E-Learning Untuk Pendidikan Khususnya Pendidikan Jarak Jauh dan Aplikasinya di Indonesia. Dalam Dewi Salma Prawiradilaga dan Eveline Siregar (Eds). Mozaik Teknologi Pendidikan. Kencana.

Sukmadinata, \& Syaodih, N. (2015). Metode Penelitian Pendidikan. Rosdakarya.

Susanti, E., \& Halimah, M. (2018). Desain Video Pembelajaran Yang Efektif Pada Pendidikan Jarak Jauh/: Studi Di Universitas Terbuka
Effective Learning Video Design in Distance Education/: Study At an Open University. Jurnal Pendidikan dan Kebudayaan, 3(2), 167-185.

Susilawati Pusat Teknologi Informasi dan Komunikasi Pendidikan dan Kebudayaan Jalan Martadinata KM, E. R., \& Tangerang Selatan, K. (2016). Swot Analysis of the Implementation of Online Ict Training for Teachers. Direvisi akhir tanggal, 1, 30-42.

Tokan, P. R. I. (2016). Manajemen Penelitian Guru. untuk Pendidikan Bermutu. PT Grasindo.

Undang-Undang RI No. 14 Tahun 2005 tentang Guru dan Dosen, Pub. L. No. 14 (2005).

Wathoni, N., Trisnawati, Fitri, \& Munib, A. (2017). Keefektifan Media Edmodo sebagai Penunjang Pembelajaran Teknologi Informasi \& Komunikasi di Sekolah Menengah Pertama. Indonesian Journal of Curriculum and Educational Technology Studies. IJCETS, 5(1), 42-48.

Widiyasari, R. (2017). Meningkatkan Aktivitas Dan Hasil Belajar Mahasiswa Menggunakan Mind Map Berbantuan E - Learning Increasing Students ' Learning Activity and. 27-43. 